University of Nebraska - Lincoln

DigitalCommons@University of Nebraska - Lincoln

USDA National Wildlife Research Center - Staff Publications
U.S. Department of Agriculture: Animal and Plant Health Inspection Service

2010

\title{
Mite-Filled Cyst on a Brown-headed Cowbird (Molothrus ater) in Florida, USA
}

\author{
Marilyn G. Spalding \\ University of Florida, SpaldingM@vetmed.ufl.edu \\ James W. Mertins \\ US Department of Agriculture \\ Matthew J. Reetz \\ University of Florida \\ Kandy L. Keacher \\ US Department of Agriculture \\ Michael L. Avery \\ US Department of Agriculture, michael.I.avery@aphis.usda.gov \\ See next page for additional authors
}

Follow this and additional works at: https://digitalcommons.unl.edu/icwdm_usdanwrc

Part of the Environmental Sciences Commons

Spalding, Marilyn G.; Mertins, James W.; Reetz, Matthew J.; Keacher, Kandy L.; Avery, Michael L.; and Greiner, Ellis C., "Mite-Filled Cyst on a Brown-headed Cowbird (Molothrus ater) in Florida, USA" (2010). USDA National Wildlife Research Center - Staff Publications. 1066.

https://digitalcommons.unl.edu/icwdm_usdanwrc/1066

This Article is brought to you for free and open access by the U.S. Department of Agriculture: Animal and Plant Health Inspection Service at DigitalCommons@University of Nebraska - Lincoln. It has been accepted for inclusion in USDA National Wildlife Research Center - Staff Publications by an authorized administrator of DigitalCommons@University of Nebraska - Lincoln. 


\section{Authors}

Marilyn G. Spalding, James W. Mertins, Matthew J. Reetz, Kandy L. Keacher, Michael L. Avery, and Ellis C. Greiner 


\section{Mite-Filled Cyst on a Brown-headed Cowbird (Molothrus ater) in Florida, USA}

Marilyn G. Spalding, ${ }^{1,6}$ James W. Mertins, ${ }^{2}$ Matthew J. Reetz, ${ }^{3,5}$ Kandy L. Keacher, ${ }^{4}$ Michael L. Avery, ${ }^{4}$ and Ellis C. Greiner ${ }^{1}$ Department of Infectious Diseases and Pathology, College of Veterinary Medicine, University of Florida, Gainesville, Florida 32611, USA; ${ }^{2}$ US Department of Agriculture, Animal and Plant Health Inspection Service, Veterinary Services, National Veterinary Services Laboratories, 1920 Dayton Ave., Ames, lowa 50010, USA; ${ }^{3}$ Department of Wildlife Ecology and Conservation, University of Florida, PO Box 110430, Gainesville, Florida 32611-0430, USA; ${ }^{4}$ US Department of Agriculture, Animal and Plant Health Inspection Service, Wildlife Services, National Wildlife Research Center, Florida Field Station, 2820 E. University Ave., Gainesville, Florida 32641, USA; ${ }^{5}$ Current address: Department of Biology, Franklin College, 101 Branigin Blvd., Franklin, Indiana 46131, USA; ${ }^{6}$ Corresponding author (email: SpaldingM@vetmed.ufl.edu)

ABSTRACT: A large, partly pedunculated mass on the scapular area of a wild-caught captive Brown-headed Cowbird (Molothrus ater) consisted of a multiloculated keratin cyst inhabited by a new species of harpirhynchid mite (Harpirhynchus quasimodo). The mass did not interfere with flight or behavior. This is the first record of such an infestation of cowbirds in Florida.

Key words: Cowbird, cyst, ectoparasite, Florida, harpirhynchid mite, Harpirhynchus quasimodo, Molothrus ater.

Birds are associated with an immense array of acarine symbionts that function in a variety of capacities (Philips, 1993; Proctor and Owens, 2000; Proctor, 2003; Knee and Proctor, 2006; Krantz and Walter, 2009). Taxonomically, these avian mites include approximately 3,000 representatives classified in approximately 60 families from all of the major acarine lineages: Ixodida, Mesostigmata, Astigmata, and Prostigmata. Ecologically, they range from commensals and benign inquilines in bird nests to virulent endo- or ectoparasites that may cause avian mortality or mutualists that feed on other avian symbionts. By far, the majority of avian-associated mites cause no harm to birds. The most diverse and numerous are the more than 2,000 known species of sarcoptiform feather mites, which are classified into 33 families, almost all of which are host-specific commensals living in the plumage of their hosts (Gaud and Atyeo, 1996; Proctor, 2003). Perhaps the most injurious avian mites are those in the astigmatan family Knemidocoptidae, which feed on and in the skin and feathers, causing mange-like diseases including scaly leg, scaly face, and depluming itch (Schlater and Mertins, 2008).

Among the other distinctive groups of mites associated with birds is the prostigmatan family Harpirhynchidae. Until recently, all mites designated as harpirynchids were exclusively associated with birds, but Bochkov et al. (1999) reclassified morphologically similar mites in the family Ophioptidae as a subfamily of Harpirhynchidae, thus adding two derived, but related genera of snake-scale parasites to the group. Avian harpirhynchids infest and feed on and in the skin of birds, causing a range of lesions that vary in extent and pathogenicity (Fain, 1994). Here we report on a wild-caught Brown-headed Cowbird (Molothrus ater) infested with a newly described species of harpirynchid mite in Florida, USA.

A female Brown-headed Cowbird was one of 48 captured 4 February 2004 to 11 February 2004 in Alachua County, Florida, USA $\left(29^{\circ} 35^{\prime} \mathrm{N}, 82^{\circ} 20^{\prime} \mathrm{W}\right)$. The birds were housed for a breeding study in groups of five to eight in outdoor cages separate from other species. Other birds housed in the same facility, but separated by $20 \mathrm{~m}$, included Monk Parakeets (Myiopsitta monachus) and Fish Crows (Corvus ossifragus). On 23 March 2004, this bird was moved to another screened building and housed with a male cowbird in a separate breeding cage. Only other paired cowbirds were similarly housed in this screened enclosure. Cages were 
disinfected with a warm bleach solution before use, although this pair replaced a previous pair in which the female had died from trauma probably caused by the male.

A dorsal mass on the bird was first noticed on 6 April, and the bird was humanely killed for postmortem examination on 15 April 2004. The mass seemed not to affect flight or behavior in any noticeable way. All other cowbirds in the study were examined in July 2004, and none was found to have similar lesions. During previous studies involving 1,065 Brown-headed Cowbirds and other species at this facility over $12 \mathrm{yr}$, no similar grossly visible or palpable lesions were observed, even though the skin was removed during examination for sarcocysts $(n=262)$.

The cyst was excised and examined grossly. A portion was preserved in $10 \%$ neutral buffered formalin, routinely embedded in paraffin, sectioned at $4 \mu \mathrm{m}$, and stained with hematoxylin and eosin. The rest of the mass was preserved in $70 \%$ ethanol and a subsample was sent to the US Department of Agriculture, National Veterinary Services Laboratories (NVSL), Ames, Iowa, USA, for mite identification. At the NVSL, several mites were mounted on a microscope slide in Hoyer's solution, allowed to clear, and examined on a compound microscope under differential interference contrast illumination at magnifications up to $400 \times$. After recognition as harpirhynchids, further specific identification was unsuccessful using published keys, descriptions, and information (Fain, 1994, 1995; Fain et al., 1999; Bochkov et al., 1999). Later, specimens were sent to a harpirhynchid specialist, A. Bochkov, who confirmed their status as newly identified species.

The gross lesion was a 1.5 -cm-diameter, soft, multilocular, and partly pedunculated cyst arising from the skin of the midline cranial scapular region (Fig. 1). The contents of the cyst locules were bright yellow-orange and friable, and had the consistency of soft wax. The mass consisted of hyperkeratotic chambers filled with

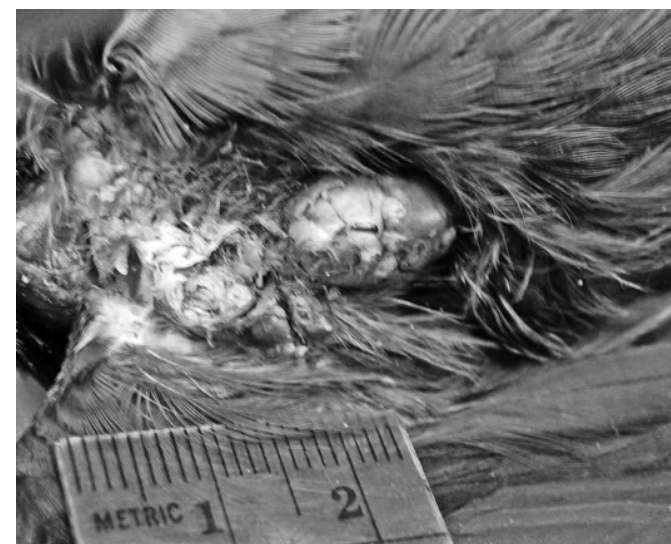

Figure 1. Appearance of the multilocular cyst on the scapular area of a Brown-headed Cowbird, after the skin has been pulled back.

live and dead mites within a matrix of keratin (Fig. 2). Almost all of the mites were within locules lined with squamous epithelium. A very few seemed to be embedded within the host subcutis. Much of the dermis surrounding the locules was fibroplastic and contained areas of lymphocytic infiltrate. Examination of the few feather follicles present on the lesion did not reveal mites within, but the multilocular nature of the lesion suggests the mite infestation might have originated within the follicles.

The cyst was similar to those described by Henry et al. (2004) and Literak et al. (2005), except that the cowbird cyst was multilocular and had a lymphocytic infiltrate. Also, the cysts on the Bearded Tit (Panurus biarmicus; Henry et al., 2004) tended to rupture when they reached $1 \mathrm{~cm}$ in diameter, and the infestation had no measureable effect on the host's health or activities. Morley and Shillinger (1937) described a mass as follows: "A female red-winged blackbird, collected in NY State, affected with an extensive tumorous growth ... was received ... in Oct., 1934. The surface was roughened and nodular in appearance, and covered by a firm crust. This growth, yellowish orange in color, was dry and crumbly in consistency, and covered the breast, the underpart of the 

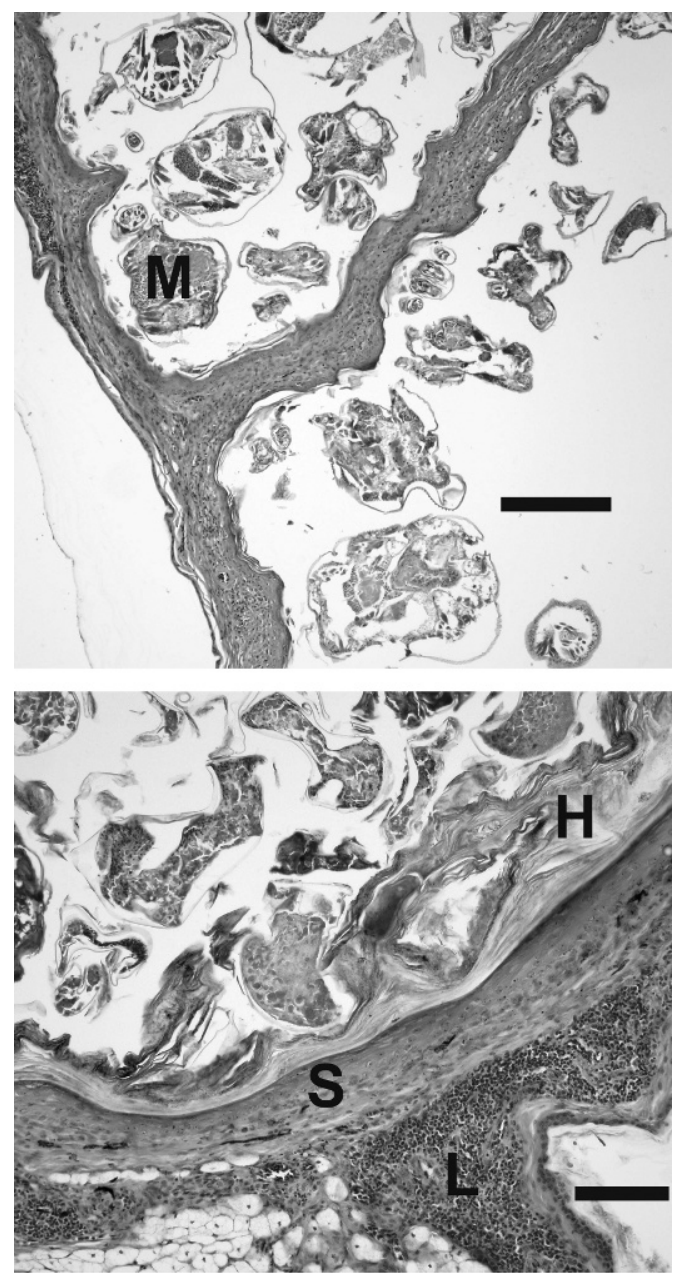

Figure 2. Photomicrographs of a section through the cyst on the scapular region of a Brown-headed Cowbird, illustrating (top) the multilocular nature of the epithelial-lined portions of the mite (M)-containing cyst (bar $=250 \mu \mathrm{m}$ ), and (bottom) the squamous epithelial wall (S) of the cyst, illustrating the multifocal lymphocyte infiltrate (L) in the dermal layer, mild fibrosis of the upper dermis and hyperkeratosis $(\mathrm{H})$ of the luminal surface $(\mathrm{bar}=100 \mu \mathrm{m})$.

neck, and parts of the thighs, and extended up under the wings onto the back. Numerous mites...H. brevis ...were found on examination of the surface material, while the deeper portions contained many eggs and a few mites."

The mite family Harpirhynchidae currently comprises fewer than 100 species worldwide, classified into 14 genera
(Bochkov et al., 1999). Avian harpirhynchid mites live on or within the skin or feather follicles of their hosts (Moss, 1979), sometimes producing a mange-like condition, with small, multiple, diffuse nodules or papules, or perhaps larger, yellowish dermal cysts in the skin of infested birds (Fain, 1994). As currently understood (Bochkov et al., 1999), most harpirhynchids are monoxenous to oligoxenous parasites, each with a limited range of no more than a few related host species. A European species, Harpirhynchus nidulans, and an American form, Harpirhynchus brevis, however, have notably long lists of recorded hosts (Moss, 1979; Henry et al., 2004).

Of the previously documented cystforming harpirynchids (Moss, 1979; Fain, 1994; Literák et al., 2005), at least three named species are reported from North American bird hosts. Harpirhynchus longipilus was found on a crossbill (Loxia sp.) in Washington, D.C., USA (Banks, 1905a, b). Harpirhynchus brevis was described from an Evening Grosbeak (Coccothraustes vespertinus; Ewing, 1911), and other authors recorded the same mite from three other bird host species (Morley and Shillinger, 1937; Chaddock, 1941; Oliver and Nelson, 1967) before Moss (1979) listed it from 29 North American passeriform bird hosts. Finally, Moss (1979) listed one North American bird host record (M. ater) for the European mite H. nidulans. Moss et al. (1968), Karstad (1970), and Bochkov and Galloway (2001) all cited an unnamed Harpirhynchus sp. from M. ater.

Our cowbird mites (Fig. 3) initially were identified as Harpirhynchus sp., but minor morphologic disparities in comparison to named forms suggested they could be an unnamed species. The type specimens of $H$. longipilus and $H$. brevis are unknown, and both are insufficiently described for current recognition (Fain, 1994; Bochkov and Mertins, 2010). Nevertheless, the description of $H$. longipilus (Banks, 1905a, b) is sufficient to 


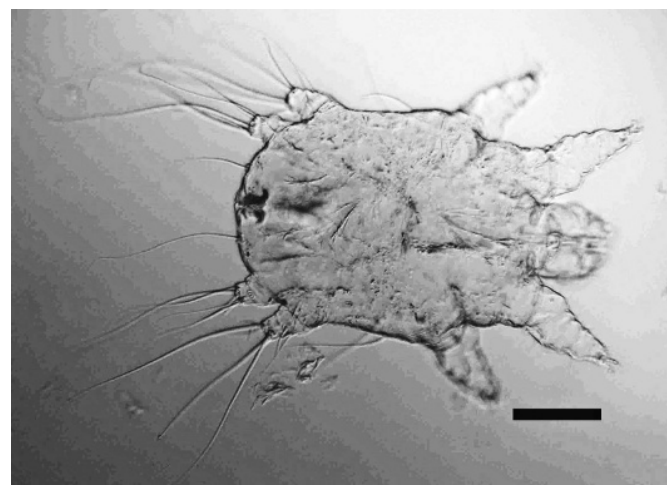

Figure 3. Photomicrograph of a female Harpirhynchus quasimodo found occupying the cystic lesion on a Brown-headed Cowbird (bar $=100 \mu \mathrm{m})$.

distinguish it from the mites we found on the cowbird. The single North American record for $H$. nidulans lists $M$. ater as the host (Moss, 1979) but must be questioned as a probable misidentification because $H$. nidulans is an Old World mite; furthermore, the Moss (1979) listing of H. brevis from $M$. ater probably was a misidentification, as well. However, at least these two Moss (1979) records and the three other cited records of Harpirhynchus sp. from $M$. ater may refer to the same mite we found, but without means or resources to check those records, the mites from Florida cowbirds were recently described and named as Harpirhynchus quasimodo (Bochkov and Mertins, 2010).

The only other record for harpirhynchid mites in Florida was from a Greater Shearwater (Puffinus gravis) from Martin County in 1993 (Foster et al., 1996; Forrester and Spalding, 2003). Mites in that collection also represent a new species because they display unusual pretarsal morphology (Mertins, unpubl.), and no other harpirhynchid records are known from any host in the order Procellariiformes (Bochkov et al., 1999).

We acknowledge the assistance of Andre Bochkov, Zoological Institute, Russian Academy of Sciences, St. Petersburg, Russia, for confirming the undescribed taxonomic status of the cyst-causing mites.

\section{LITERATURE CITED}

Banks, N. 1905a. A treatise of the Acarina, or mites. Proceedings of the United States National Museum 28: 1-109.

. 1905b. Descriptions of some new mites. Proceedings of the Entomological Society of Washington 7: 133-142.

Bochkov, A. V., and T. D. Galloway. 2001. Parasitic cheyletoid mites (Acari: Cheyletoidea) associated with passeriform birds (Aves: Passeriformes) in Canada. Canadian Journal of Zoology 79: 2014-2028.

-, and J. W. Mertins. 2010. Harpirhynchus quasimodo sp. n. (Acariformes: Harpirhynchidae), a new species parasitizing Molothrus ater (Passeriformes: Icteridae) in Florida, U.S.A. International Journal of Acarology 36: 83-87.

-, S. V. Mironov, and A. Fain. 1999. Phylogeny and host-parasite relationships of the mite family Harpirhynchidae (Acari, Prostigmata). Acarina 7: 69-87.

Chaddock, T. T. 1941. Rare mites found on Wisconsin blackbird. Wisconsin Conservation Bulletin 6: 33-34.

EwING, H. E. 1911. New predaceous and parasitic Acarina. Psyche 18: 37-43.

FAIN, A. 1994. New observations on the Harpirhychidae Dubinin, 1957 (Acari: Prostigmata). I. The subgenus Harpirhynchus (Harpyrhynchoides) Fain, 1972. Bulletin de l'Institut Royal des Sciences Naturelles de Belgique, Entomologie 64: 109-144.

- 1995. New observations on the Harpirhychidae Dubinin, 1957 (Acari: Prostigmata). II. On some new or little-known taxa in the Harpirhynchinae. Bulletin de l'Institut Royal des Sciences Naturelles de Belgique, Entomologie 65: 73-100.

—, A. V. Bochkov, and S. V. Mironov. 1999. A contribution to the systematics of the mite family Harpirhynchidae (Acari: Cheyletoidea). Acarologia 40: 37-54.

Forrester, D. J., and M. G. Spalding. 2003. Parasites and diseases of wild birds in Florida. University Press of Florida, Gainesville, Florida, $1132 \mathrm{pp}$.

Foster, G. W., J. M. Kinsella, R. D. Price, J. W. Mertins, and D. J. Forrester. 1996. Parasitic helminths and arthropods of Greater Shearwaters (Puffinus gravis) from Florida. Journal of the Helminthological Society of Washington 63: 83-88.

Gaud, J., and W. T. Atyeo. 1996. Feather mites of the world (Acarina, Astigmata): The supraspecific taxa. Part I. Text. Musée Royal de l'Afrique Centrale, Annales, Sciences Zoologiques 277: 1-193.

Henry, P.-Y., B. Poulin, F. Rousset, F. Renaud, and F. Thomas. 2004. Infestation by the mite 
Harpirhynchus nidulans in the bearded tit (Panurus biarmicus). Bird Study 51: 34-40.

Karstad, L. 1970. Diseases diagnosed in free-living birds. Ontario Bird Banding 6: 6-17.

Knee, W., And H. Proctor. 2006. Keys to the families and genera of blood and tissue feeding mites associated with Albertan birds. Canadian Journal of Arthropod Identification 2. doi: 10.3752/ cjai.2006.02. http://www.biology.ualberta.ca/bsc/ ejournal/kp02/kp_02.html. Accessed March 2009.

Krantz, G. W., and D. E. Walter (eds.). 2009. A manual of acarology. 3rd Edition. Texas Tech University Press, Lubbock, Texas, 807 pp.

Literák, I., J. Chytil, A. Trnka, A. Fain, and V. Tukač. 2005. Subalar cutaneous cysts with Harpirhynchus nidulans in bearded tits and hawfinches in Central Europe. Avian Pathology 34: $26-28$.

Morley, L. C., and J. E. Shillinger. 1937. Parasitic tumors in wild birds. Journal of the American Veterinary Medical Association 91: 94-97.

Moss, W. W. 1979. Patterns of host-specificity and co-evolution in the Harpyrhynchidae. In Recent advances in acarology, Vol. II, J. G. Rodriguez (ed.). Academic Press, New York, New York, pp. 379-384.
J. H. Oliver, Jr., and B. C. Nelson. 1968. Karyotypes and developmental stages of Harpyrhynchus novoplumaris sp. n. (Cheyletoidea: Harpyrhynchidae), a parasite of North American birds. Journal of Parasitology 54: 377-392.

Oliver, J. H. Jr., and B. C. Nelson. 1967. Mite chromosomes: An exceptionally small number. Nature 214: 809.

Philips, J. R. 1993. Avian mites. Compendium on Continuing Education for the Practicing Veterinarian 15: 671-683.

Proctor, H. C. 2003. Feather mites (Acari: Astigmata): Ecology, behavior, and evolution. Annual Review of Entomology 48: 185-209.

, AND I. Owens. 2000. Mites and birds: Diversity, parasitism and coevolution. Trends in Ecology and Evolution 15: 358-364.

Schlater, J. L., J. W. Mertins. 2008. Mange. In Manual of diagnostic tests and vaccines for terrestrial animals (mammals, birds and bees), 6th Edition, OIE Biological Standards Commission (eds.). Office International des Epizooties, Paris, France, pp. 1255-1266.

Submitted for publication 10 January 2010. Accepted 28 May 2010. 